\title{
Contribution to the Study of Biotechnological Control Techniques Applied Against Biocorrosion Oil Installations
}

\author{
FAIZA KHOUKHI ${ }^{1}$, NACER-EDDINE DJELALI ${ }^{2 *}$, SALIMA KEBOUCHE ${ }^{3}$, \\ MOHAMED LAMINE GANA ${ }^{4}$ \\ ${ }^{1}$ Laboratory of Electrochemical Corrosion and Metallurgy Technologies \& Development Division, Sonatrach, Algeria - \\ Faculty of sciences, Department of chemistry M'hamed Bouguera University of Boumerdes, Algeria \\ ${ }^{2}$ Treatment and Formatting of the Polymers Laboratory (L.T.M.F.P) M'hamed Bouguera University of Boumerdes, Algeria \\ ${ }^{3}$ Laboratory of VALCOR, Department of Biology, Faculty of sciences M'hamed Bouguera University of Boumerdes, Algeria \\ ${ }^{4}$ Laboratory of Bacterial Corrosion Technologies \& Development Division, Sonatrach, Algeria
}

Abstract.The biological activity of oil extracted from green algae has long been known, but evaluation of bimolecular activities contained in this oil on an industrial scale, especially in the oil industry, was the objective of our research project. The first stapes of this study is to extract the essential oil from green algae marine Ulva Lactuca in our region, obtained by extraction/purification method based on hydro distillation and methanol extraction, the work performed at the laboratories of Sonatrach (SH/DTD/AUI/CEM). The second stapes is to evaluate the potential of these algae extracts on microbiologically influenced corrosion. After chemical-physic characterization of two bio naturals products $A$ and $B$, we test their effectiveness as a bactericide on bacterial corrosion of carbon steel in water contained sulfate reducing bacteria by electrochemical analysis techniques (Open-circuit potential/OCP and Electrochemical Impedance Spectroscopy/EIS).

Keywords: biocorrosion, electrochemical, algae, FTIR, EIS

\section{Introduction}

Plants offer a real potential for research of new molecules with inhibitory activity used for therapeutic purposes [1,2]. Few plant species are known and only a minority of them is chemically explored [1]. The marine environment is an infinite source of active molecules original chemical structure, such as green algae whose biological activity has long been known [3-5]. Many studies highlighted the biological activity of metabolites extracted from algae [6,7]. The evaluation activity of the essential oil extracted from green algae marine Ulva Lactuca, harvested from the Algerian coast, applied against microbiologically influenced corrosion in the oil industry, was the subject of this study.

\section{Materials and methods}

\subsection{Preparation of algae extract}

The Ulva Lactuca green algae were harvested in the month of April 2015, on the coast of DellysBoumerdes at the Mediterranean Sea waters in Algeria where it grows in abundance in the spring.

Two extraction methods were used in this study, the hydro distillation one which gives as bio natural product $\mathrm{A}$ and methanol extraction which gives as bio natural product $\mathrm{B}$.

Characterization techniques of extracts product

\section{Organoleptic and chemical-physic properties ${ }^{\#}$}

All properties such; $p \mathrm{H}$, density, viscosity, appearance, color and odor were determined and recorded in Table 1.

\# Quality control analysis was performed in the Control and Fluid Treatment Laboratory at DTD/SONATRACH - Boumerdes - Algeria.

$\overline{\text { *email: n.djelali@univ-boumerdes.dz }}$ 
Table1. Organoleptic and chemical-physic characteristic of bio natural's products A and B extracted from green marine algae Ulva Lactuca

\begin{tabular}{|c|c|c|c|c|c|c|c|c|c|}
\hline Characteristic & Aspect & Odor & Color & $\mathbf{T}^{\circ} \mathbf{C}$ & pH & $\begin{array}{c}\text { Density } \\
\text { g/cm }\end{array}$ & $\begin{array}{c}\text { Viscosity } \\
\text { at } 20^{\circ} \mathrm{C} \\
\text { cP } \\
\end{array}$ & \multicolumn{2}{|c|}{ Solubility } \\
\hline Product "A" & Liquid & algal & colorless & 21 & 7.14 & 1.001 & 1.40 & \multirow{2}{*}{$\begin{array}{c}\text { Water } \\
\text { Alcohol } \\
\text { hydrocarbon } \\
\text { water } \\
\text { Alcohol } \\
\text { hydrocarbon }\end{array}$} & \multirow{2}{*}{$\begin{array}{c}\text { Soluble } \\
\text { Soluble } \\
\text { Insoluble } \\
\text { Soluble } \\
\text { Soluble } \\
\text { insoluble }\end{array}$} \\
\hline Product "B" & Liquid & algal & $\begin{array}{c}\text { Green } \\
\text { algae }\end{array}$ & 21 & 4.67 & 1.002 & 2.35 & & \\
\hline
\end{tabular}

\subsection{Infrared spectrum analysis}

Analysis by infrared spectrum** allowed us to characterize our product using spectrometer Shimatzu FTIR 8900 by formulating a drop extract of green algae on a $\mathrm{KBr}$ pellet. The IR spectrum were determined in Figure 1.

**This analysis was conducted at Chemical Laboratory at Science Faculty at M'hamed Bougara University of Boumerdes Algeria.

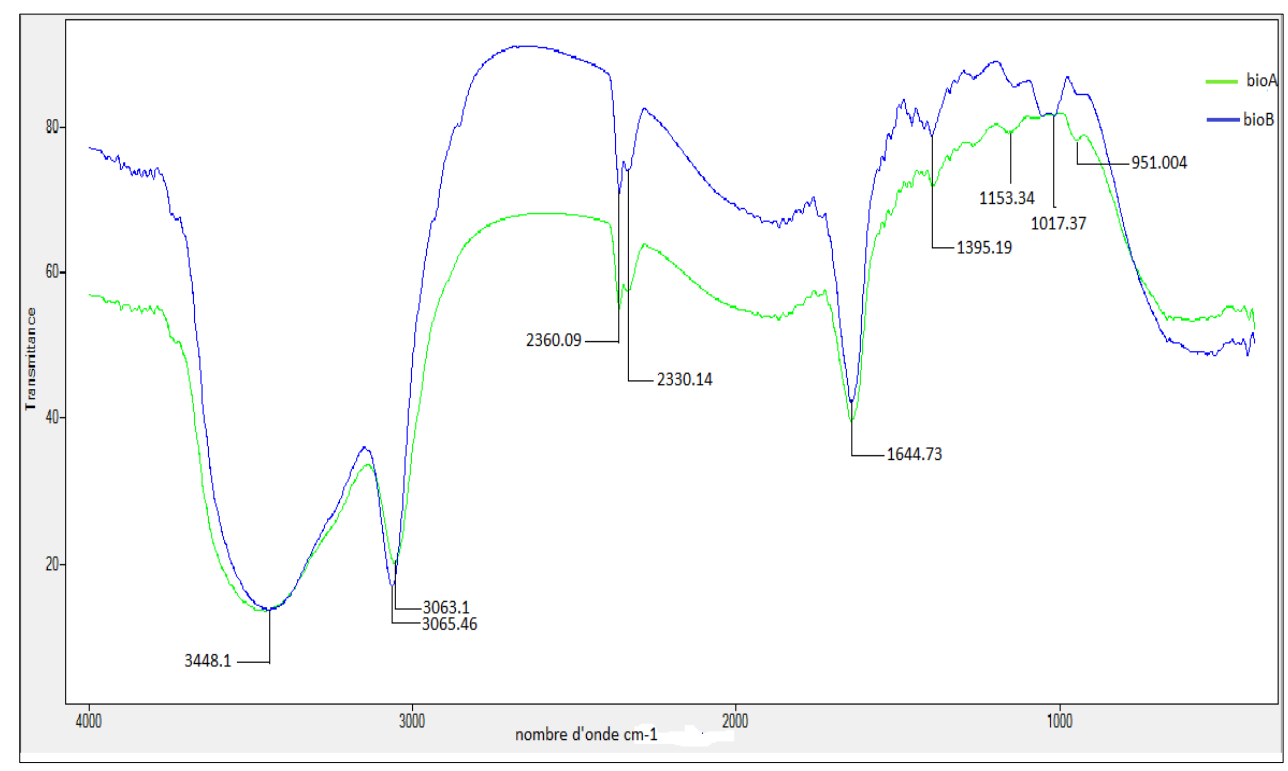

Figure 1. IR spectrum of extract green algae marine Ulva Lactuca by two extractions methods

In the literature, the use of green plants as inhibitors of metal corrosion is explained by its high molecule having $\mathrm{O}-\mathrm{H}$ groups, $\mathrm{C}=\mathrm{O}$ and $\mathrm{C}=\mathrm{C}$ groups in their chemical structure. Hamdy and ElGendy (2013) studied the inhibitory action of extract of Henna Lauzenia Inermis and its major constituents on the steel corrosion. The inhibitory efficacy of the extract from the Asteraceae was evaluated on steel by Garai et al, (2012). Deng and Li (2012) used the Phillyrin and Verbascoside, active compound extract from Jaminum Diflorum sheet steel for protection against corrosion. Xanthyletin the active compound of the extract of leaves of Citrus aurantifolia was used as an inhibitor of steel corrosion by Saratha and al, (2009) [8-11].

All these works cited and others performed in the same context [12-17] reported high values of the inhibitory efficiency as a function of alcohol, esther, aldehyde, amine, ketone and acid; identified in chemical structures of compound majority extracts.

Our case confirms by Infrared spectrum analysis given by the Figure 1 and which has the following:

The spectrum presents an intense and broad absorption band around $3400-2500 \mathrm{~cm}^{-1}$ indicates the presence of hydroxyl group $\mathrm{OH}$. 
The spectrum has an intense absorption band around $1820-1660 \mathrm{Cm}^{-1}$ indicated the presence of carboxyl group $\mathrm{C}=\mathrm{O}$.

The spectrum presents a medium intensity absorption band around $3400-3300 \mathrm{Cm}^{-1}$ indicated the presence of $\mathrm{NH}$ group, making the presence of amine.

The spectrum has an average intensity of absorption band around $1650-1450 \mathrm{Cm}^{-1}$ indicated the presence of the double bond $\mathrm{C}=\mathrm{C}$.

The spectrum shows an absorption peak very fine average intensity at $2250 \mathrm{Cm}^{-1}$ which confirmed the presence of nitrile compound and the benzene ring.

According functions present in this spectrum confirming that the bimolecular extracted from green algae marine that is responsible for protection of carbon steel against microbiologically influenced corrosion is an amine or amine derivative.

\subsection{Selection of bacterial strain tested}

The bacterial strain tested Sulfate reducing bacteria say SRB is isolated from industrial water injection wells in oil field Hassi Messaoud - BRN in southern Algeria. These bacteria were incubated at $37^{\circ} \mathrm{C}$ in a specific culture medium for proliferation prepared according to the API RP 38-1999 Standard [18].

\subsection{Efficiency test of bio natural products extracted from Ulva Lactuca by bacteriogical test}

Pre-culture was prepared with water injection which is enriched with chemical constituents of specific culture medium of SRB. The pre-culture is then distributed in bottles of penicillin, bubbled with nitrogen and sterilize at $120^{\circ} \mathrm{C}$ for $20 \mathrm{~min}$ at 1 bar pressure. After sterilization the flasks are left twice in series of four bottles and each series is inoculated with $1 \mathrm{~mL}(10 \%)$ SRB strain. Incubation of pre-culture is carried out at $37^{\circ} \mathrm{C}$ for $48 \mathrm{~h}$.

Bio naturals products A and B extracted from Ulva Lactuca is then added to the vials prepared to selected concentrations of $0,5,10,15,20,30,50,100,150,200,250,300,350$ and 400 ppm.

Then incubated at $37^{\circ} \mathrm{C}$ until 28 days. The procedure of reading penicillin bottles during incubation period. Upon visual inspection of bottles, two case:

$1^{\text {st }}$ case: bottle positive $(+)$ : medium turning from black by SRB, which shows that the bio natural product is ineffective.

$2^{\text {nd }}$ case: Bottle negative (-): not turning to black by SRB, which shows that the bio natural product is effective.

We note that contamination by SRB in entreated medium is $10^{4}$ germs $/ \mathrm{mL}$, but after injection of bio natural's products extracted from green algae marine Ulva Lactuca A and B with differences doses, no contamination were recorded during 28 days of incubation at $37^{\circ} \mathrm{C}$. The results are given in annex A.

Annex A. Results of monitoring treatment efficacy anti corrosion by bio natural products "A" and "B" in liquid medium

\begin{tabular}{|c|c|c|c|c|c|c|c|c|c|c|c|c|c|c|c|c|c|c|c|c|c|c|c|c|c|c|c|c|c|}
\hline \multirow{3}{*}{$\begin{array}{c}\text { Injection } \\
\text { Date }\end{array}$} & \multirow{3}{*}{$\begin{array}{l}\text { Tested } \\
\text { Product }\end{array}$} & \multicolumn{28}{|c|}{ Tacubation period (day) bacterinl sowings made on the iajection } \\
\hline & & 1 & 2 & 3 & 4 & 5 & 6 & 7 & 8 & 9 & 10 & 11 & 12 & 13 & 14 & 15 & 16 & 17 & 18 & 19 & 20 & 21 & 22 & 23 & 24 & 25 & 26 & 27 & 28 \\
\hline & & \multicolumn{28}{|c|}{ 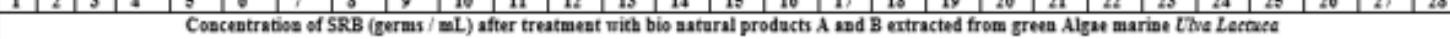 } \\
\hline $\begin{array}{l}\text { 0 ppm } \\
18.03 .2015\end{array}$ & $\begin{array}{l}\text { SRB } \\
\text { (Btanx) }\end{array}$ & 0 & 0 & 0 & $10^{*}$ & $10^{*}$ & $10^{\circ}$ & $10^{\circ}$ & $10^{*}$ & $10^{4}$ & 100 & $10^{*}$ & $10^{4}$ & $10^{4}$ & $10^{\circ}$ & $10^{*}$ & $10^{4}$ & $10^{\circ}$ & $10^{*}$ & $10^{4}$ & $10^{4}$ & $10^{*}$ & $10^{*}$ & $10^{4}$ & $10^{+}$ & $10^{*}$ & $10^{4}$ & $10^{4}$ & $10^{\circ}$ \\
\hline \multirow{2}{*}{${ }_{15}^{5}$ ppm } & Product $" \boldsymbol{A}$ ' & 0 & 0 & 0 & 0 & 0 & 0 & 0 & 0 & 0 & 0 & 0 & 0 & 0 & 0 & 0 & 0 & 0 & 0 & 0 & 0 & 0 & 0 & 0 & 0 & 0 & 0 & 0 & 0 \\
\hline & Product ' $\mathrm{B}$ ' & 0 & 0 & 0 & 0 & 0 & 0 & 0 & 0 & 0 & 0 & 0 & 0 & 0 & 0 & 0 & 0 & 0 & 0 & 0 & 0 & 0 & 0 & 0 & 0 & 0 & 0 & 0 & 0 \\
\hline \multirow[t]{2}{*}{${ }_{18}^{10} \mathrm{ppm} .015 .2015$} & Product " $A$ " & 0 & 0 & 0 & 0 & 0 & 0 & 0 & 0 & 0 & 0 & 0 & 0 & 0 & 0 & 0 & 0 & 0 & 0 & 0 & 0 & 0 & 0 & 0 & 0 & 0 & 0 & 0 & 0 \\
\hline & Product ' $\mathrm{B}$ ' & 0 & 0 & 0 & 0 & 0 & 0 & 0 & 0 & 0 & 0 & 0 & 0 & 0 & 0 & 0 & 0 & 0 & 0 & 0 & 0 & 0 & 0 & 0 & 0 & 0 & 0 & 0 & 0 \\
\hline \multirow[t]{2}{*}{${ }_{15}^{15} \mathrm{ppm} .2015$} & Product ' $A$ ' & 0 & 0 & 0 & 0 & 0 & 0 & 0 & 0 & 0 & 0 & 0 & 0 & 0 & 0 & 0 & 0 & 0 & 0 & 0 & 0 & 0 & 0 & 0 & 0 & 0 & 0 & 0 & 0 \\
\hline & Product ' $\mathrm{B}$ ' & 0 & 0 & 0 & 0 & 0 & 0 & 0 & 0 & 0 & 0 & 0 & 0 & 0 & 0 & 0 & 0 & 0 & 0 & 0 & 0 & 0 & 0 & 0 & 0 & 0 & 0 & 0 & 0 \\
\hline
\end{tabular}




\begin{tabular}{|c|c|c|c|c|c|c|c|c|c|c|c|c|c|c|c|c|c|c|c|c|c|c|c|c|c|c|c|c|c|}
\hline \multirow[t]{2}{*}{\begin{tabular}{|l|}
20 \\
18.03 .2015 \\
18.03
\end{tabular}} & Product ${ }^{A}{ }^{*}$ & 0 & 0 & 0 & 0 & 0 & - & 0 & 0 & 0 & 0 & 0 & 0 & 0 & 0 & 0 & 0 & 0 & 0 & 0 & 0 & 0 & 0 & 0 & - & 0 & 0 & 0 & 0 \\
\hline & Product ' $\mathrm{B}$ ' & 0 & 0 & 0 & 0 & 0 & 0 & 0 & 0 & 0 & 0 & 0 & 0 & 0 & 0 & 0 & 0 & 0 & 0 & 0 & 0 & 0 & 0 & 0 & 0 & 0 & 0 & 0 & 0 \\
\hline \multirow{2}{*}{$\begin{array}{l}30 \mathrm{ppm}^{3} \\
18.03 .2015\end{array}$} & Product ' $A$ ' & 0 & 0 & 0 & 0 & 0 & 0 & 0 & 0 & 0 & 0 & 0 & 0 & 0 & 0 & 0 & 0 & 0 & 0 & 0 & 0 & 0 & 0 & 0 & 0 & 0 & 0 & 0 & 0 \\
\hline & Product ' $\mathrm{B}$ ' & 0 & 0 & 0 & 0 & 0 & - & 0 & 0 & 0 & 0 & 0 & 0 & 0 & 0 & 0 & 0 & 0 & 0 & 0 & 0 & 0 & 0 & 0 & 0 & 0 & 0 & 0 & 0 \\
\hline \multirow[t]{2}{*}{$\begin{array}{l}{ }^{60} \mathrm{ppm} \\
18.03 .2016\end{array}$} & Product ${ }^{\prime}{ }^{*}$ & 0 & 0 & 0 & 0 & 0 & 0 & 0 & 0 & 0 & 0 & 0 & 0 & 0 & 0 & 0 & 0 & 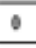 & 0 & 0 & 0 & 0 & 0 & 0 & - & 0 & 0 & 0 & 0 \\
\hline & Product 'B' & 0 & 0 & 0 & 0 & 0 & 0 & 0 & 0 & 0 & 0 & 0 & 0 & 0 & 0 & 0 & 0 & 0 & 0 & 0 & 0 & 0 & 0 & 0 & 0 & 0 & 0 & 0 & 0 \\
\hline \multirow[t]{2}{*}{$\begin{array}{l}{ }_{180}^{180} \mathrm{pm} \\
18.2015\end{array}$} & Product ' $A$ ' & 0 & 0 & 0 & 0 & 0 & 0 & 0 & 0 & 0 & 0 & 0 & 0 & 0 & 0 & 0 & 0 & 0 & 0 & 0 & 0 & 0 & 0 & 0 & 0 & 0 & 0 & 0 & 0 \\
\hline & Product 'B' & 0 & 0 & 0 & 0 & 0 & 0 & 0 & 0 & 0 & 0 & 0 & 0 & 0 & 0 & 0 & 0 & 0 & 0 & 0 & 0 & 0 & 0 & 0 & 0 & 0 & 0 & 0 & 0 \\
\hline \multirow{2}{*}{$\begin{array}{l}150 \mathrm{ppm} \\
18.03 .2015\end{array}$} & Product ' $A$ ' & 0 & 0 & 0 & 0 & 0 & 0 & 0 & 0 & 0 & 0 & 0 & 0 & 0 & 0 & 0 & 0 & 0 & 0 & 0 & 0 & 0 & 0 & 0 & 0 & 0 & 0 & 0 & 0 \\
\hline & \begin{tabular}{|l|} 
Product 'B' \\
\end{tabular} & 0 & 0 & 0 & 0 & 0 & 0 & 0 & 0 & 0 & 0 & 0 & 0 & 0 & 0 & 0 & 0 & 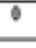 & 0 & 0 & 0 & 0 & 0 & 0 & 0 & 0 & 0 & 0 & 0 \\
\hline \multirow{2}{*}{$\begin{array}{l}200 \mathrm{ppm} \\
18.03 .2015\end{array}$} & Product"A" & 0 & 0 & 0 & 0 & 0 & 0 & 0 & 0 & 0 & 0 & 0 & 0 & 0 & 0 & 0 & 0 & 0 & 0 & 0 & 0 & 0 & 0 & 0 & 0 & 0 & 0 & 0 & 0 \\
\hline & Product'B' & 0 & 0 & 0 & 0 & 0 & 0 & 0 & 0 & 0 & 0 & 0 & 0 & 0 & 0 & 0 & 0 & 0 & 0 & 0 & 0 & 0 & 0 & 0 & 0 & 0 & 0 & 0 & 0 \\
\hline \multirow{2}{*}{\begin{tabular}{|l|}
250 ppm \\
18.03 .2015 \\
\end{tabular}} & Product" $A$ " & 0 & 0 & 0 & 0 & 0 & 0 & 0 & 0 & 0 & 0 & 0 & 0 & 0 & 0 & 0 & 0 & 0 & 0 & 0 & 0 & 0 & 0 & 0 & 0 & 0 & 0 & 0 & 0 \\
\hline & Product 'B" & 0 & 0 & 0 & 0 & 0 & 0 & 0 & 0 & 0 & 0 & 0 & 0 & 0 & 0 & 0 & 0 & 0 & 0 & 0 & 0 & 0 & 0 & 0 & 0 & 0 & 0 & 0 & 0 \\
\hline \multirow{2}{*}{$\begin{array}{l}300 \mathrm{ppm} \\
18.03 .2015\end{array}$} & Product" $A "$ & 0 & 0 & 0 & 0 & 0 & 0 & 0 & 0 & 0 & 0 & 0 & 0 & 0 & 0 & 0 & 0 & 0 & 0 & 0 & 0 & 0 & 0 & 0 & 0 & 0 & 0 & 0 & 0 \\
\hline & Product 'B" & 0 & 0 & 0 & 0 & 0 & 0 & 0 & 0 & 0 & 0 & 0 & 0 & 0 & 0 & 0 & 0 & 0 & 0 & 0 & 0 & 0 & 0 & 0 & 0 & 0 & 0 & 0 & 0 \\
\hline \multirow{2}{*}{$\begin{array}{l}350 \mathrm{ppm} \\
18.03 .2015\end{array}$} & Product"A" & 0 & 0 & 0 & 0 & 0 & 0 & 0 & 0 & 0 & 0 & 0 & 0 & 0 & 0 & 0 & 0 & 0 & 0 & 0 & 0 & 0 & 0 & 0 & 0 & 0 & 0 & 0 & 0 \\
\hline & Product'B" & 0 & 0 & 0 & 0 & 0 & 0 & 0 & 0 & 0 & 0 & 0 & 0 & 0 & 0 & 0 & 0 & 0 & 0 & 0 & 0 & 0 & 0 & 0 & 0 & 0 & 0 & 0 & 0 \\
\hline \multirow{2}{*}{\begin{tabular}{|l|}
$400 \mathrm{ppm}$ \\
18.03 .2015
\end{tabular}} & Product $\mathrm{A}^{\prime \prime}$ & 0 & 0 & 0 & 0 & 0 & 0 & 0 & 0 & 0 & 0 & 0 & 0 & 0 & 0 & 0 & 0 & 0 & 0 & 0 & 0 & 0 & 0 & 0 & 0 & 0 & 0 & 0 & 0 \\
\hline & Product' $\mathrm{B}^{\prime \prime}$ & 0 & 0 & 0 & 0 & 0 & 0 & 0 & 0 & 0 & 0 & 0 & 0 & 0 & 0 & 0 & 0 & 0 & 0 & 0 & 0 & 0 & 0 & 0 & 0 & 0 & 0 & 0 & 0 \\
\hline
\end{tabular}

\section{Results and discussions}

\subsection{Electrochemical tests}

The studied corrosion reaction occurs at the interface of electrode. The material used as the working electrode is carbon steel shade API 5L X60. Table 2 gives as the chemical composition of the steel sample.

Table 2. Chemical composition of carbon steel (in mass \%)

\begin{tabular}{|l|l|l|l|l|l|l|l|l|l|l|}
\hline Elements (\%) & $\mathrm{C}$ & $\mathrm{Si}$ & $\mathrm{Mn}$ & $\mathrm{Ni}$ & $\mathrm{Cr}$ & $\mathrm{P}$ & $\mathrm{S}$ & $\mathrm{Mo}$ & $\mathrm{Cu}$ & $\mathrm{Fe}$ \\
\hline API5L X60 & 0.22 & 0.23 & 1.31 & 0.044 & 0.05 & 0.013 & 0.01 & 0.016 & 0.06 & 98.047 \\
\hline
\end{tabular}

Evaluation of corrosion rate in terms of carbon steel time in the presence of SRB (test blank - without treatment)

Table 3 and Figure 2 represent corrosion rate evolution of carbon steel immersed in injection water enriched and contemned by $10^{2}$ germs $/ \mathrm{mL}$ of SRB versus time of incubation.

Table 3. Results of monitoring corrosion rate of carbon steel immersed in contaminated water injection by the SRB versus time of incubation at $37^{\circ} \mathrm{C}$

\begin{tabular}{|c|c|c|c|c|c|c|c|c|c|c|c|}
\hline Time, (h) & 4 & 8 & 24 & 48 & 72 & 96 & 120 & 144 & 168 & 240 & 336 \\
\hline $\begin{array}{c}\text { Corrosion Rate } \\
\text { (mm/year) }\end{array}$ & 0.050 & 0.130 & 1.837 & 3.366 & 7.301 & 8.209 & 5.345 & 4.069 & 2.959 & 1.506 & 0.106 \\
\hline $\begin{array}{c}\text { Corrosion Rate } \\
\text { (mpy) } \\
\text { (Mil par year) }\end{array}$ & 2.001 & 5.146 & 72.31 & 132.5 & 287.4 & 323.2 & 210.4 & 160.2 & 116.5 & 59.29 & 4.172 \\
\hline
\end{tabular}




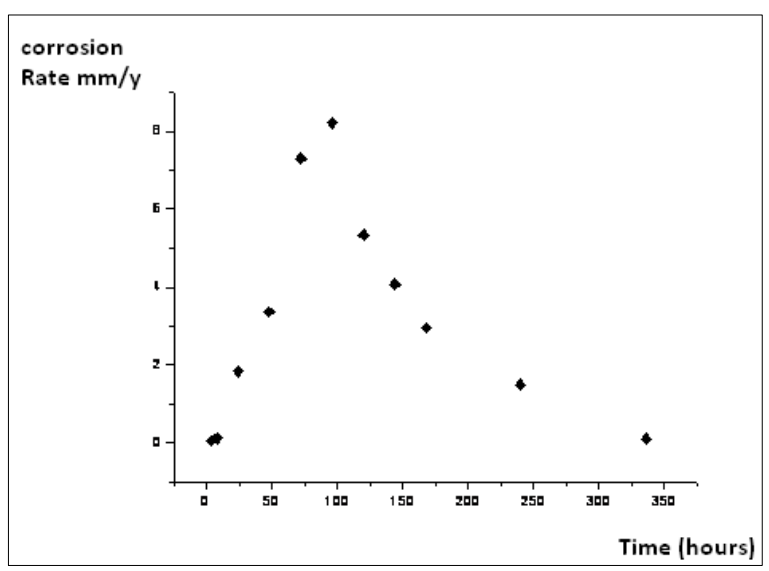

Figure 2. Monitoring evaluation of corrosion rate of carbon steel submerged in a contaminated water injection by the SRB versus time of incubated at $37^{\circ} \mathrm{C}$

The shape of the curve increases as a function of incubation time of the SRB. A corrosion rate recorded during 24 to $48 \mathrm{~h}$ is greater than $3.366 \mathrm{~mm} /$ year or $132.5 \mathrm{mpy}$, after $72 \mathrm{~h}$ the steel corrosion rate reached a maximal, $8.2 \mathrm{~mm} /$ year or $323.2 \mathrm{mpy}$ was detected at the 4th Day or $96 \mathrm{~h}$ of incubations. A decrease in the corrosion rate was recorded from the 5th day. We note that this curve is identical to the bacterial growth curve, the rate of carbon steel corrosion is maximal when the bacteria are in the exponential phase or their growth rate $\mu$ is maximal.

For low speeds recorded, the 7th and 8th day of incubation, are due to the low concentration of SRB in water due to the depletion of minerals and trace elements necessary for their growth and the accumulation of waste metabolisms that become toxic for bacteria and leads to cell autolysis.

Monitoring the open-circuit potential $(O C P)$ is intended to achieve the stabilization time of metalsolution interface. Table 4 gives as the variation of potential for a shade carbon steel electrode API5L $\mathrm{X} 60$ in the presence of SRB in injection water before and after treatment with bio natural's products A and $\mathrm{B}$.

Table 4. Corrosion Potential of steel measured in the various environments in the presence of SRB $\left(10^{2}\right.$ germs $\left./ \mathrm{mL}\right)$ in medium treated with bio natural's products A and B

\begin{tabular}{|c|c|c|c|}
\hline Electrolysis & $\begin{array}{c}\text { Incubation time } \\
\text { (h) }\end{array}$ & $\begin{array}{c}\text { Stabilization } \\
\text { Time } \\
(s)\end{array}$ & $\begin{array}{c}\text { OCP } \\
\boldsymbol{m V / E C S}\end{array}$ \\
\hline $\begin{array}{c}\text { Injection water contemned by 10 } 0^{2} \text { germs/ml SRB } \\
\text { of bio natural Product A }\end{array}$ & 72 & 4500 & -774 \\
\hline $\begin{array}{c}\text { Injection water contemned by SRB and treated with 5 ppm } \\
\text { Injection water contemned by SRB and treated with 30 } \\
\text { ppm of bio natural product A }\end{array}$ & 120 & 4500 & -643 \\
\hline $\begin{array}{c}\text { Injection of water contemned by SRB and treated with 5 } \\
\text { ppm of bio natural product B }\end{array}$ & 120 & 80000 & -696 \\
\hline $\begin{array}{c}\text { Injection of water contemned by SRB and treated with 30 } \\
\text { ppm of bio natural product B }\end{array}$ & 120 & 8500 & -300 \\
\hline
\end{tabular}

Potential measurement is followed for an immersion time of $72 \mathrm{~h}$ for the blank sample and 5 days for treated one with bio natural product. The corrosion potential recorded in the presence of SRB equal to (-774 mV/SCE); According to Pourbaix's diagram [12].

This potential is identical to that of steel immersed in a solution contaminated by SRB so that we localized corrosion and iron dissolution.

For values of (-696 to $-300 \mathrm{mV} / \mathrm{SCE})$ stored in Table 4 and obtained in the presence of treatment with bio natural products $\mathrm{A}$ and $\mathrm{B}$; are noble and tend toward more positive potentials. 
The film formed on steel area prevents from oxide reduction reactions and anion exchange to take place, so that SRB metabolism was blocked and bio natural's products adhere to the area of steel by forming a protective film.

Bacteria present in an aqueous medium rich of nutriment necessary for their metabolism and development behave according to the potential Pourbaix's diagram iron- $p \mathrm{H}$ [19]. This diagram describes the relationship between the corrosion influenced by microorganisms (MIC) and the electrochemical characteristics of the steel corrosion.

Carbon steel alloys present as micro-heterogeneous material which confers in a different electrochemical behavior by corrosion metabolism of bacteria present in the medium and their effect on the material. Forming a biofilm layer on the area of working electrode followed by an attack of corrosive medium (rich in chlorides and sulfates water injection) caused corrosion by SRB which explains the recorded values of potential corrosion as a function of time $(-774 \mathrm{mV} / \mathrm{SCE})$; Forming a protective layer after injection of the biomolecular on our steel explains the recorded values of corrosion potential versus time ranging from (-696 to $-335 \mathrm{mV} / \mathrm{SCE})$.

Scanning electron microscopy (SEM) was used for characterizing the surface morphological properties of SRB biofilm was presented in Figure 3 and observations of protective film formed by bio natural's product A and B extracted from green algae marine Ulva Lactuca over steel surface, were presented in Figure 4 and Figure 5.
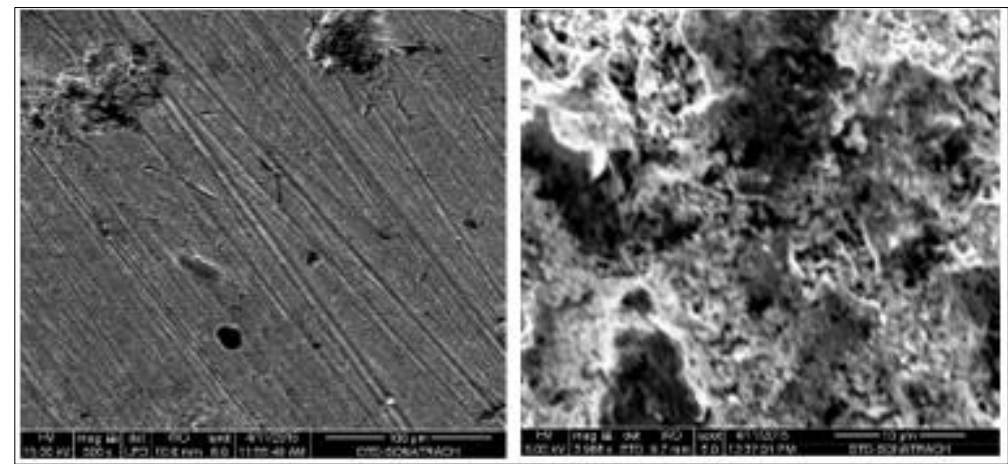

Figure 3. SEM micrographs of steel immersed in contemned medium by the SRB for 10 days

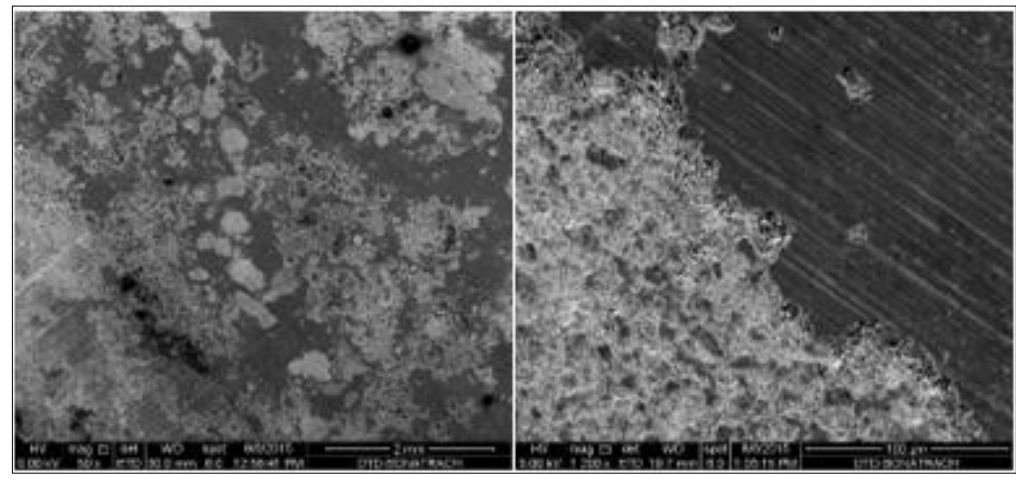

Figure 4. SEM micrographs of steel immersed in contemned medium by the SRB treated with bio natural's product A with $30 \mathrm{ppm}$ 


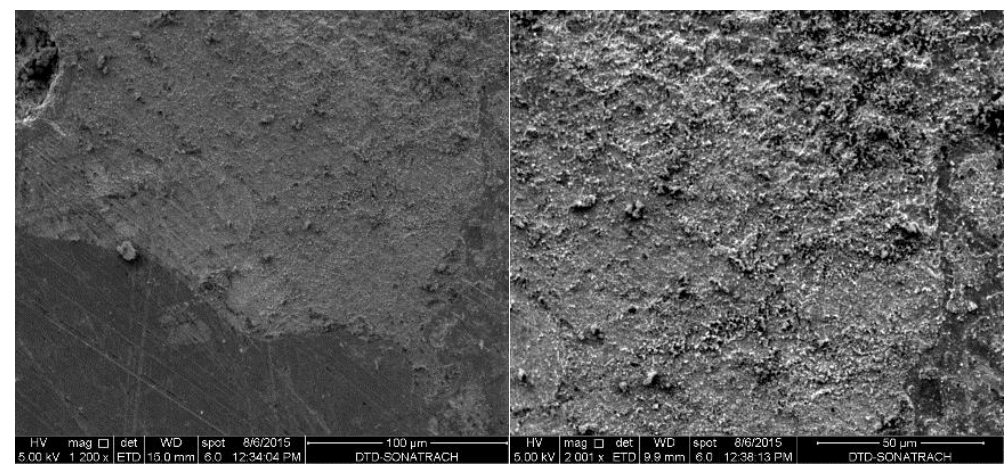

Figure 5. SEM micrographs of steel immersed in contemned medium by the SRB treated with bio natural's product B with $30 \mathrm{ppm}$

\subsection{Electrochemical impedance spectroscopy (EIS)}

Electrochemical impedance spectroscopy technique was used to confirm corrosion of carbon steel immersed in injection water contemned by SRB with presence and absence of Ultra Lactuca's extract product used as treatment against microbiologically influenced corrosion. This technique has the advantage to minimize disruption of metal-solution interface, as the superimposed alternative signal courant to continue signal courant is low $( \pm 10 \mathrm{mV})$. The impedance curves are shown by the Nyquist plots and Bode.

The intersection of semi-circles on the Nyquist plots with the real axis (Z') represents the solution resistance $\left(R_{s}\right)$ at high frequency and the charge transfer resistance $\left(R_{t c}\right)$ at low frequency which give as polarization resistance $\left(\mathrm{R}_{\mathrm{p}}\right)$ [20].

\subsection{Test with bio natural product $A$}

Table 5. Electrochemical parameters obtained by EIS of carbon steel immersed in a medium treated with the bio natural product $\mathrm{A}$ at various concentrations

\begin{tabular}{|c|c|c|c|c|c|c|}
\hline $\begin{array}{c}\text { Concentrations } \\
\text { (ppm) }\end{array}$ & $\begin{array}{c}0 \\
\text { Parameters }\end{array}$ & 5 & 10 & 15 & 20 & 30 \\
\hline OCP $(\mathbf{m v} / \mathbf{E C S})$ & -725 & -664 & -660 & -644 & -460 & -460 \\
\hline $\mathbf{R}_{\mathbf{s}}\left(K \Omega . \mathrm{cm}^{2}\right)$ & 0.0088 & 0.0082 & 0.0179 & 0.0176 & 0.0980 & 0.0980 \\
\hline $\mathbf{R}_{\mathbf{t c}}\left(K \Omega . \mathrm{cm}^{2}\right)$ & 0.177 & 3.837 & 21.167 & 35.549 & 295.862 & 433.722 \\
\hline $\mathbf{R}_{\mathbf{p}}\left(K \Omega . \mathrm{cm}^{2}\right)$ & 0.186 & 3.846 & 21.185 & 35.567 & 295.96 & 433.82 \\
\hline $\mathbf{C}_{\mathrm{dl}}\left(\mu \mathrm{F} / \mathrm{cm}^{2}\right)$ & 1900 & 6000 & 190 & 190 & 190 & 190 \\
\hline $\begin{array}{c}\text { Maximum phase Angle } \theta \\
(\text { deg })\end{array}$ & $-60^{\circ}$ & $-48^{\circ}$ & $-46^{\circ}$ & $-50^{\circ}$ & $-45^{\circ} ;-20^{\circ}$ & $-44^{\circ} ;-55^{\circ}$ \\
\hline
\end{tabular}




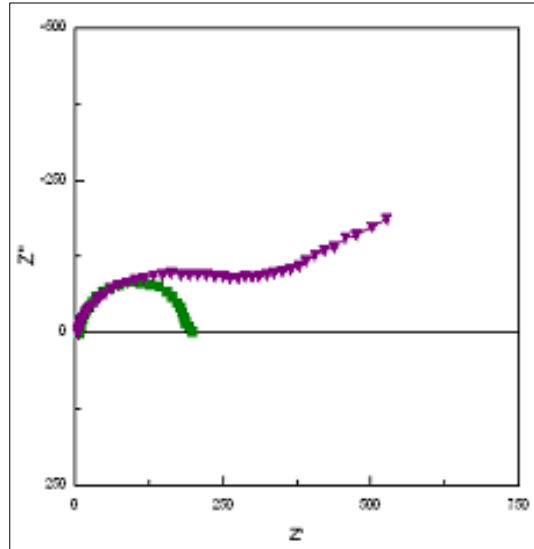

Nyquist diagram

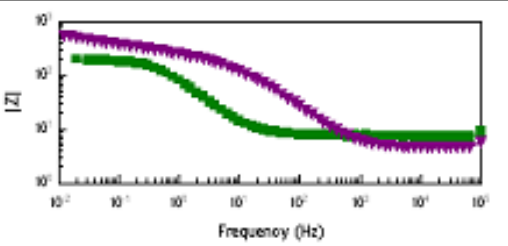

- Blank

mm 5 ppm

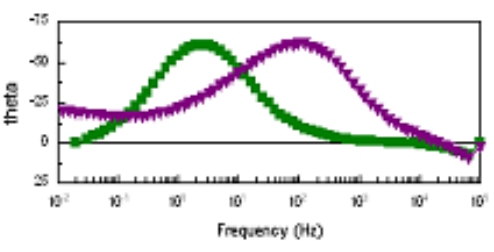

Bode diagram

Figure 6. Nyquist and Bode diagrams obtained by EIS of steel immersed in contemned injection water by $10^{2}$ germs $/ \mathrm{mL}$ of SRB (Blank) and treated with $5 \mathrm{ppm}$ of bio natural product $\mathrm{A}$

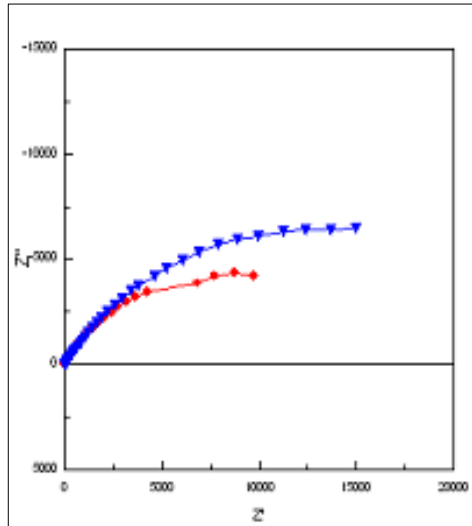

Nyquist diagram
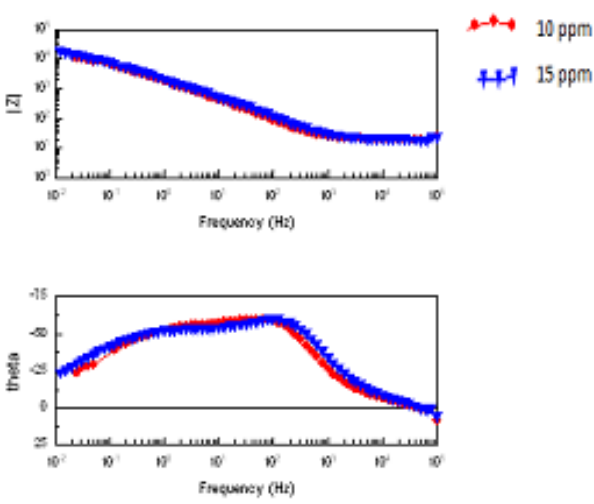

Bode diagram

Figure 7. Nyquist and Bode diagrams obtained by EIS of steel immersed in contemned injection water by $10^{2}$ germs $/ \mathrm{mL}$ of SRB and treated with 10 and $15 \mathrm{ppm}$ of bio natural product $\mathrm{A}$
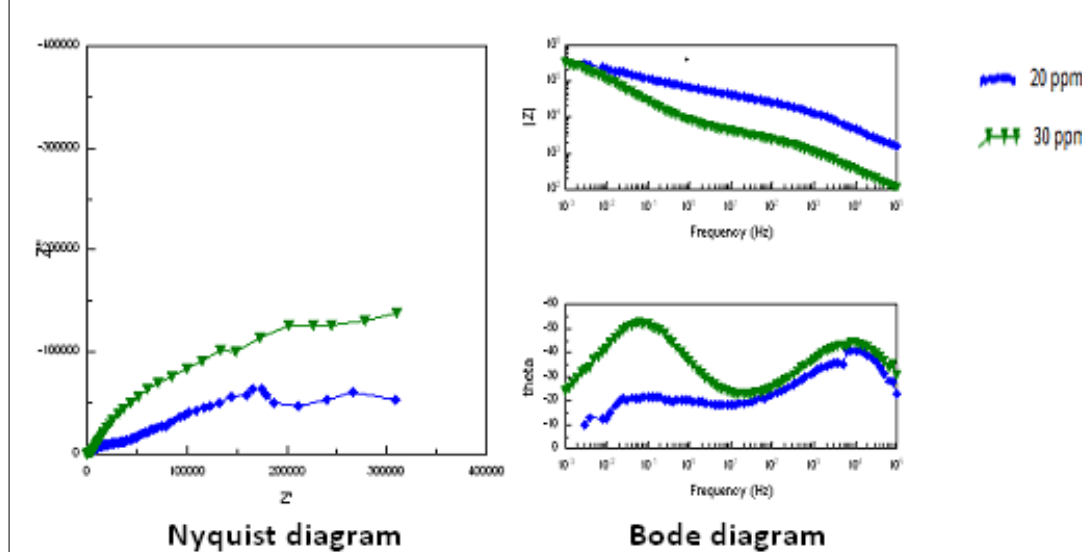

HH $30 \mathrm{ppm}$

Nyquist diagram

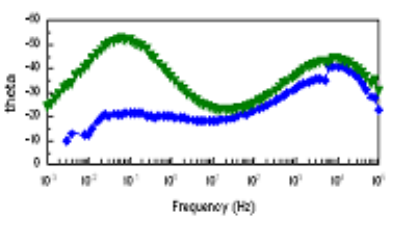

Bode diagram

Figure 8. Nyquist and Bode diagrams obtained by EIS of steel immersed in contemned injection water by $10^{2}$ germs $/ \mathrm{mL}$ of SRB and treated with 20 and $30 \mathrm{ppm}$ of bio natural product $\mathrm{A}$ 
From Figure 6 to Figure 8 is found that the semi-circles of impedance diagram showing the control of corrosion steel by the charge transfer process. Thus, the resistance solution is low for contemned medium with SRB.

The impedance parameters given in Table 5 show an increase in charge transfer resistance, a decrease in the values of the capacity of double layer $\mathrm{C}_{\mathrm{dl}}$ according to the increase in the concentration of bio natural product $\mathrm{A}$; these results indicate that the algae extract obtained by the hydro distillation method, inhibits the process of microbiologically influenced corrosion of steel by adsorption mechanism. $\mathrm{C}_{\mathrm{dl}}$ is inversely proportional with polarization resistor $R_{p}$, resistance of material increases when a protective film was formed on metal surface and the electron cloud ion exchange (anion, cation) taken place and the double layer has a fine appearance order values of $10^{-5}$ to $10^{-7} \mathrm{Farad} / \mathrm{cm}^{2}$, confirming reaction of biomolecular by inhibiting adsorption mechanism to the metal surface.

\subsection{Test with bio natural product $B$}

Table 6. Electrochemical parameters obtained by EIS of carbon steel immersed in a medium treated with the bio natural product $\mathrm{B}$ at various concentrations

\begin{tabular}{|c|c|c|c|c|c|c|}
\hline Concentrations ppm & $\begin{array}{c}0 \\
\text { Parameters }\end{array}$ & 5 & 10 & 15 & 20 & 30 \\
\hline OCP $(\mathbf{m v} / \mathbf{E C S})$ & -725 & -697 & -675 & -660 & -644 & -485 \\
\hline $\mathbf{R}_{\mathbf{s}}\left(K \Omega \cdot \mathrm{cm}^{2}\right)$ & 0.0088 & 0.0155 & 0.0179 & 0.0177 & 0.0177 & 0.207 \\
\hline $\mathbf{R}_{\mathbf{t c}}\left(K \Omega \cdot \mathrm{cm}^{2}\right)$ & 0.177 & 2.448 & 11.678 & 29.700 & 40.04 & 399.01 \\
\hline $\mathbf{R}_{\mathbf{p}}\left(K \Omega \cdot \mathrm{cm}^{2}\right)$ & 0.186 & 2.464 & 11.696 & 29.718 & 40.057 & 399.22 \\
\hline $\mathbf{C}_{\mathbf{d l}}\left(\mu \mathrm{F} / \mathrm{cm}^{2}\right)$ & 1900 & 340 & 140 & 170 & 200 & 270 \\
\hline $\begin{array}{c}\text { Maximum phase Angle } \theta \\
(\text { deg })\end{array}$ & $-60^{\circ} \mathrm{C}$ & $-48^{\circ}$ & $-46^{\circ}$ & $-50^{\circ}$ & $-45^{\circ} ;-20^{\circ}$ & $-44^{\circ} ;-55^{\circ}$ \\
\hline
\end{tabular}

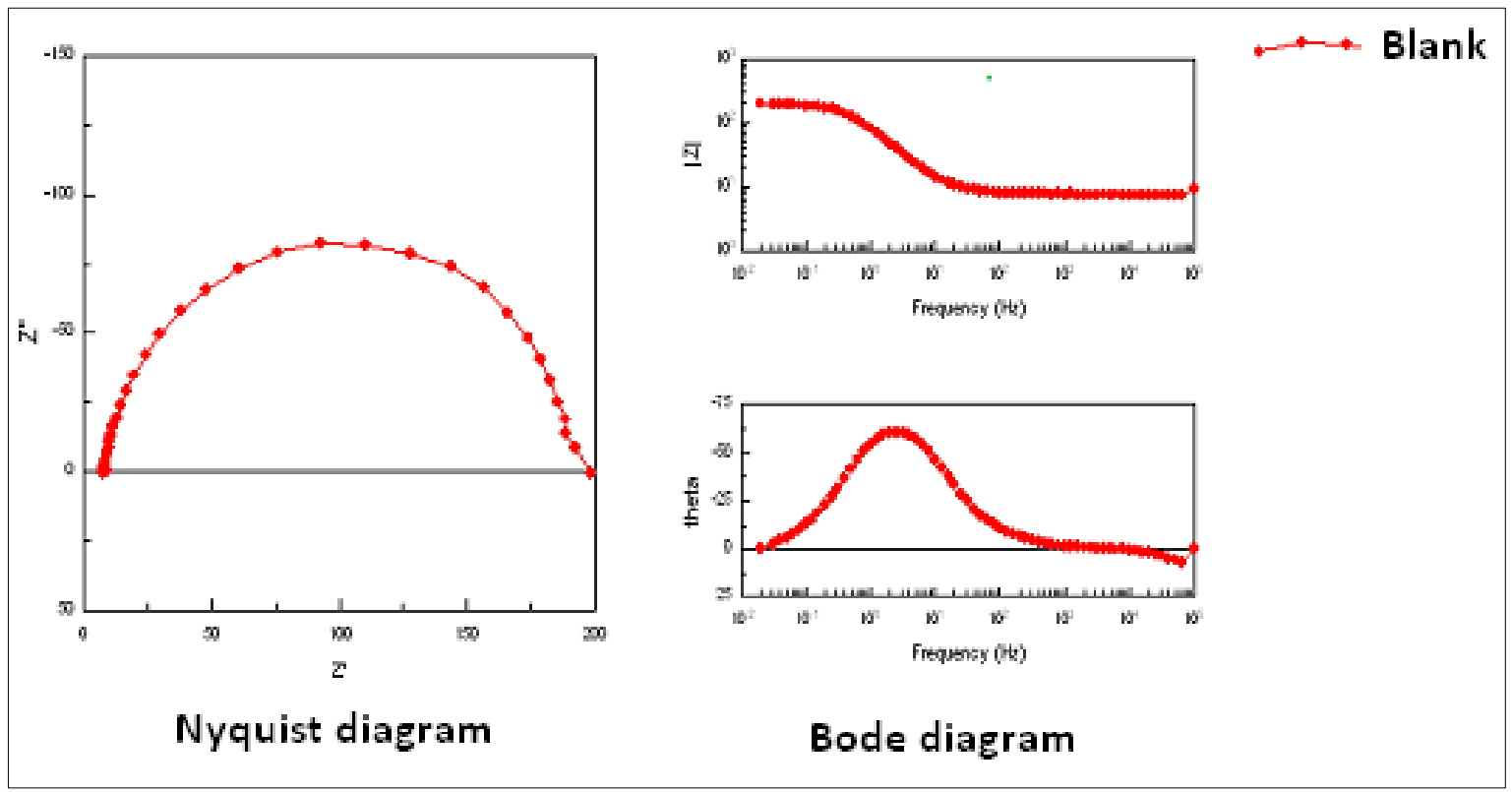

Figure 9. Nyquist and Bode diagrams obtained by EIS of steel immersed in contemned injection water by $10^{2}$ germs $/ \mathrm{mL}$ of SRB 


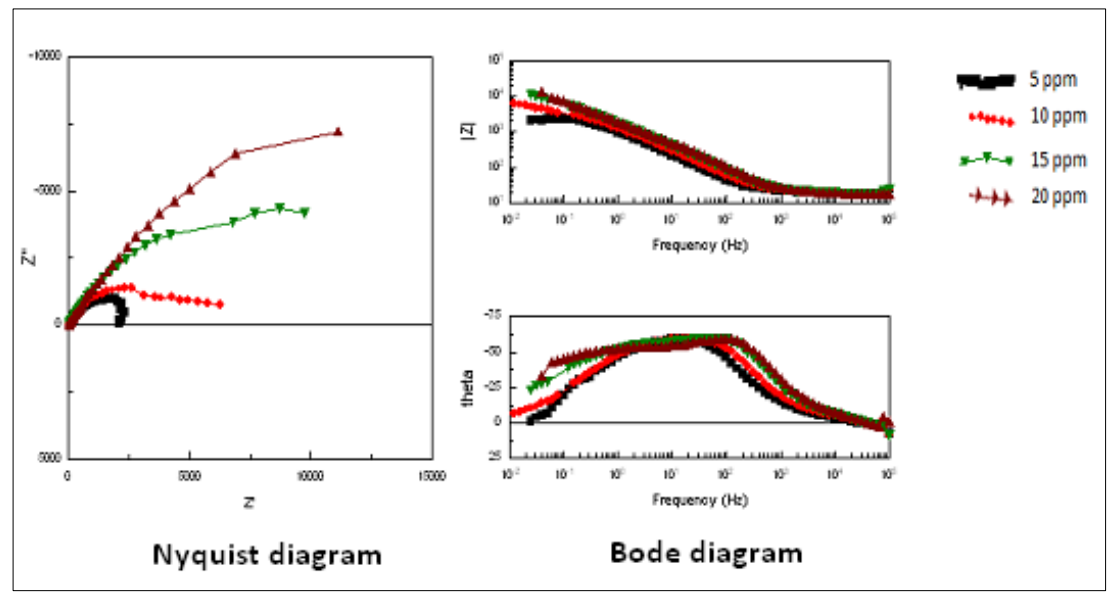

Figure 10. Nyquist and Bode diagrams obtained by EIS of steel immersed in a contemned injection water by $10^{2}$ germs $/ \mathrm{mL}$ of SRB and treated with various bio natural product $\mathrm{B}(5,10,15$ and $20 \mathrm{ppm})$

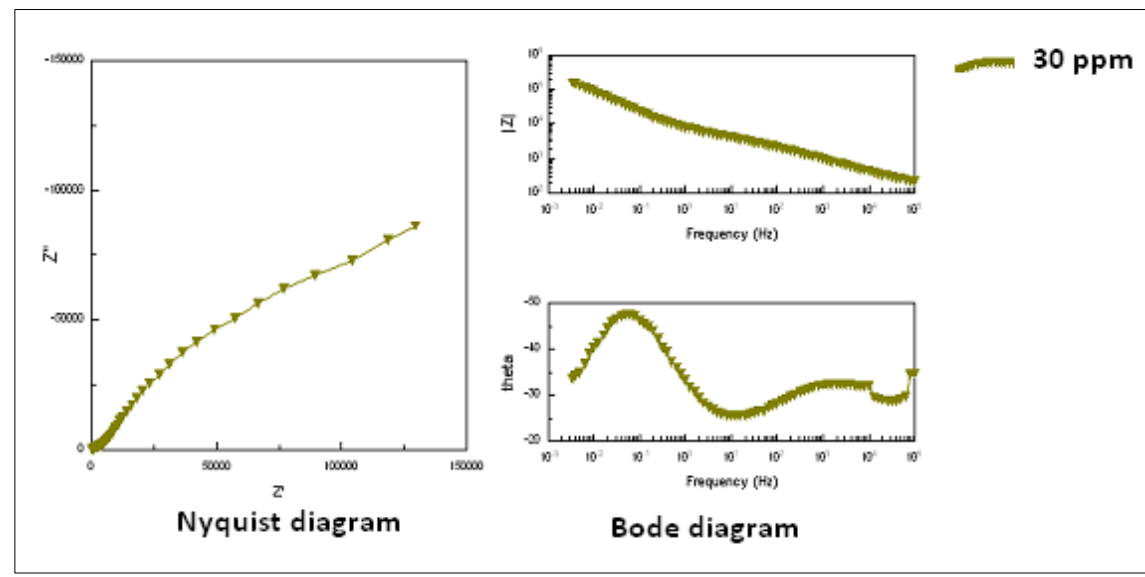

Figure 11. Nyquist and Bode diagrams obtained by EIS of steel immersed in contemned injection water by $10^{2}$ germs $/ \mathrm{mL}$ of SRB and treated with $30 \mathrm{ppm}$ of bio natural product $\mathrm{B}$

According to Figures 9, 10 and 11; we note that when bio natural product B was injected impedance diagram shows the same trend capacitive loops whose diameter increases with increasing concentration.

The results given in table. 6 indicate an increase in charge transfer resistance $\mathrm{R}_{\mathrm{tc}}$ values and a decrease in capacity of double layer $\mathrm{C}_{\mathrm{dl}}$ values according to the increase of bio natural product $\mathrm{B}$ concentration, this decrease is associated with the adsorption of biomoleculs of algae extract at steel surface.

Polarization resistance $\mathrm{R}_{\mathrm{p}}$ of blank sample is $0.186 \mathrm{K \Omega} . \mathrm{cm}^{2}$ after injection various concentration of bio natural product $\mathrm{B}, \mathrm{R}_{\mathrm{p}}$ values increase to $11.696 \mathrm{K \Omega} . \mathrm{cm}^{2}$ with $10 \mathrm{ppm}$ and to $399.22 \mathrm{K \Omega} . \mathrm{cm}^{2}$ with 30 ppm. The capacities of the double layer are weak, values order are $10^{-5}$ Farads $/ \mathrm{cm}^{2}$.

The phase angle $\theta$ indicated was greater than $-54^{\circ}$ for each concentration, with respect to the dose of $30 \mathrm{ppm}$ scanning steel surface was performed by two phase angles $\theta 1$ equal $-32^{\circ}$ and $\theta 2$ equal $-49^{\circ}$ confirming the presence of a protective Film formed on steel surface by bio natural product B extracted by methanol extraction method from green algae marine Ulva Lactuca.

\section{Conclusions}

The purpose of this study was the characterization of biofilm on carbon steel immersed in industrial injection water contemned by sulfate-reducing bacteria SRB. The main conclusions we reached are: 
The injection water from the oil field Hassi Messaoud-BRN in south Algeria is rich by nutriments representing the various energy sources; such as carbon, sulfur, calcium, magnesium, these elements are necessary for enzyme activity and have a catalytic role of the bacterial cell.

Microbiological analysis of this water highlights sulfate-reducing bacteria with concentration of $10^{4}$ germs $/ \mathrm{ml}$. The evolution of bacterial corrosion rate versus time incubation of steel immersed in injection water contemned by SRB has given us very high values in the presence of SRB from the 3rd day of incubation and decreases the 5th day.

The extraction of active moleculs of green algae marine Ultra Lactuca harvested from the Algerian coast; by two methods of extraction hydro distillation and methanol extraction yields two bio natural products $\mathrm{A}$ and $\mathrm{B}$ containing molecules responsible for the inhibition of bacterial corrosion by their protective potency of carbon steel against the effect of SRB.

An infrared spectrum analysis allowed us to identify the essential functions of biomoleculs acting as microbiologically influenced corrosion inhibitor, and acting either on the product microbiologically influenced corrosion in steel surface or on the SRB growth metabolism.

The use of electrochemical techniques to confirm the protective power characterizing these biomoleculs shows that the presence of both bio natural products. Corrosion rate decreases after four hours after the injection of each product in contemned medium with $10^{2}$ germs $/ \mathrm{mL}$ of SRB, incubated for 36 to $72 \mathrm{~h}$.

The deferent techniques show the effectiveness of bio natural products for steel protection against MIC, high polarizations resistance are obtained during this study as a function of increasing concentration of bio naturals products tested.

With regard to the electrochemical impedance spectroscopy technique; semi-circles obtained increase for each concentration as from $5 \mathrm{ppm}$ to $30 \mathrm{ppm}$, satisfactory results were obtained confirming the protective film formed by extracted biomoleculs from green algae marine Ulva Lactuca against corrosion caused by SRB.

\section{References}

1. *** UNEP-WCMC, Cambridge, England Biodiversity data sourcebook., 2002

2. GUINOISEAU E., Molécules antibactériennes issues d'huile essentielles: séparation, identification et mode d'action. Univ. Corse pascale PAOLI-UMR-CNRS., 2010

3. SMIT A.J., Journal of applied phycology., 16, 2004, p 254-262.

4. PAUL V.J., Fenical W., Bioorganism marina chemistry, 1, 1987, p 1-29.

5.STEINBERG P.D., SCHNEIDER KJELLEBERG S., Chemical defenses of sea weeds against microbial colonization, biodegradation., 8, 1997, p.211- 220.

6. FAULKNER D.J., Marine natural products, natural's products report., 19, 2002, p.1-48.

7. EL KOURI A., BULTEL - PONCE V., ASSOBHEI O., ETAHIRI S., Review of biology and biotechnology., 3(1), 2004, p.29-36.

8. HAMDY A., EL-GENDY N.S., Egyptian Journal of Petroleum., 22, 2013, p.15-25.

9. GARAI S., JAISANKAR P., SINGH J.K., ELANGO A., Corr. Sci., 60, 2012, p.193-204.

10. DENG S., LI X., Corr. Sci., 64, 2012, p.253-262.

11. SARATHA S., PRIYA S.V., THILAGAVATHY P., E-Journal of chemistry, Index., 6, 2009, p.785795.

12. CHADWICK L.R., PAULI G.F., FARNSWORTH N.R., Phytomedicine., vol.13(1-2),2006, p.119131

13. ATINGA E.I., UMORENA S.A., UDOUSOROA I.I., EBENSOB E.E., UDOHA A.P., Green Chemistry Letters and Reviews., 3(2),2010, p.61- 68

14. ABD EL-AZIZ S., FOUDA A., NOFAL M., MAHER R., Blue ocean research journals., 4(5),2015, p.328 - 337

15. BENMESSAOUD LEFT D., ZERTOUBI M., IRHZO A., AZZI M., J. Mater. Environ. Sci., 4(6), 2013, p. 855-866 
16. OBOT I.B., OBI-EGBEDI N.O., Int. J. Electrochem. Sci., 4, 2009, p.1277 - 1288

17.SANGEETHA M., RAJENDRAN S., SATHIYABAMA J., KRISHNAVENI A., Portugaliae Electrochimica Acta., 31(1), 2013, p. 41-52

18.***API-RP38, Recommended Practice for biological analysis of subsurface injection waters, $3^{\text {ed }}$, American Petroleum institute, Washington, D.C, Texas, 1975.

19. AJONES A.D., PENNY S.A., related electrochemical characteristics of microbial metabolism and Iron corrosion. Ind. Eng. Chem. Res., 39, 2000, p. 575 - 582.

20. BARD R.J., FAULKNER L.R., Electrochemical Methods., Wiley \& Sons, New York, 2001, p.368416

$\overline{\text { Manuscript received: } 7.09 .2020}$ 